Article

\title{
Method of Averaging the Effective Thermal Conductivity Based on Thermal Response Tests of Borehole Heat Exchangers
}

\author{
Aneta Sapińska-Śliwa, Tomasz Sliwa *, Kazimierz Twardowski, Krzysztof Szymski, \\ Andrzej Gonet and Paweł Żuk \\ Laboratory of Geoenergetics, Faculty of Drilling, Oil and Gas, AGH University of Science and Technology, Al. \\ Mickiewicza 30, 30-059 Krakow, Poland; ans@agh.edu.pl (A.S.-Ś.); twardows@agh.edu.pl (K.T.); \\ szymskikrzysztof@gmail.com (K.S.); gonet@agh.edu.pl (A.G.); pawel.zuk@vp.pl (P.Ż.) \\ * Correspondence: sliwa@agh.edu.pl; Tel.: +48-12-617-2217
}

Received: 12 May 2020; Accepted: 15 July 2020; Published: 20 July 2020

check for updates

\begin{abstract}
This work concerns borehole heat exchangers and their testing using apparatus for thermal response tests. In the theoretical part of the article, an equation was derived from the known equation of heat flow, on which the interpretation of the thermal response test was based. The practical part presents the results of several measurements taken in the AGH Laboratory of Geoenergetics. They were aimed at examining the potential heat exchange capacity between the heat carrier and rock mass. Measurement results in the form of graphs are shown in relation to the examined, briefly described wells. Result analysis made it possible to draw conclusions regarding the interpretation of the thermal response test. The method of averaging the measurement results was subjected to further study. The measuring apparatus recorded data at a frequency of one second, however such accuracy was too large to be analyzed efficiently. Therefore, an average of every $1 \mathrm{~min}$, every $10 \mathrm{~min}$, and every $60 \mathrm{~min}$ was proposed. The conclusions stemming from the differences in the values of effective thermal conductivity in the borehole heat exchanger, resulting from different data averaging, were described. In the case of three borehole heat exchangers, ground properties were identical. The effective thermal conductivity $\lambda_{\text {eff }}$ was shown to depend on various borehole heat exchanger (BHE) designs, heat carrier flow geometry, and grout parameters. It is important to consider the position of the pipes relative to each other. As shown in the charts, the best (the highest) effective thermal conductivity $\lambda_{\text {eff }}$ occurred in BHE- 1 with a coaxial construction. At the same time, this value was closest to the theoretical value of thermal conductivity of rocks $\lambda$, determined on the basis of literature. The standard deviation and the coefficient of variation confirmed that the effective thermal

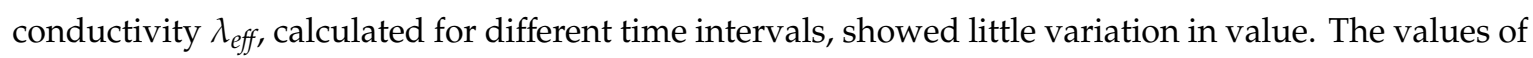
effective thermal conductivity $\lambda_{e f f}$ for each time interval for the same borehole exchanger were similar in value. The lowest values of effective thermal conductivity $\lambda_{\text {eff }}$ most often appeared for analysis with averaging every $60 \mathrm{~min}$, and the highest-for analysis with averaging every $1 \mathrm{~min}$. For safety reasons, when designing (number of BHEs), safer values should be taken for analysis, i.e., lower, averaging every $60 \mathrm{~min}$.
\end{abstract}

Keywords: thermal response test; borehole heat exchangers; underground thermal energy storage; geoenergetics; geothermal heat pumps; geothermal energy; geothermics

\section{Introduction}

In the era of depleting conventional energy sources and increasingly pro-ecological policies, e.g., those of the European Union, it became natural to focus the attention on alternative energy sources. 
Among them are not only those safe for the environment, but also those with renewable resources. New solutions in the field of heating and air conditioning were developed [1]. Due to the rapid growth of geothermal energy development, individual users gaining independency in acquisition and distribution of geothermal energy became common. Geothermal energy based on heat pumps can support traditional installations, or, in favourable conditions, entirely replace them on quite a large scale [2].

An example of such solutions are borehole heat exchangers (BHEs) [3]. This article concerns research conducted in the Laboratory of Geoenergetics, Department of Drilling, Oil and Gas AGH UST [4,5], which aimed to analyze thermal response tests (TRTs). Based on the tests performed, the potential for heat exchange in the BHE [6] could be estimated. As a result, rational design of an underground thermal energy storage (UTES) became possible, particularly the determination of the number of boreholes required [7].

Correct and most accurate determination of the ground parameters is a key element when designing the installation of the so-called shallow geothermal energy [8]. One of the methods of temperature change determination in the BHE is to introduce a thermometer [9] based on fiber optic links into the exchanger. Sensors measure the flowing medium at a fixed depth [10]. In a classic thermal response test (Figure 1), the working fluid is heated on the surface and injected into the borehole heat exchanger. Based on the temperature changes obtained over time, further parameters are determined. A slightly different method is to use heating cables directly in the borehole and then monitor the heat flow after heating the rock mass [11]. In many cases of using vertical exchangers, thermal parameters of the ground are also influenced by subsurface waters [12]. In the event of their intensive occurrence, BHEs may interact with one another in a way that impairs or improves the parameters of the system (depending on their distribution), which should be especially considered in the process of system design [13]. Currently, this interaction becomes an increasingly considered parameter when determining the thermal parameters of the ground. Measuring circulation parameters of the heat carrier is conducted by using appropriate temperature and flow sensors (Figure 1) on the BHE [14]. Such solution ensures the measurement of a fluid's temperature changes depending on the flow. The effect of the atmospheric environment in which the borehole heat exchanger is located is also worth noting (Figure 2). Temperature difference between the heat carrier in the connection pipes and atmospheric air can be significant. Depending on the method of averaging the results, the value of calculated effective thermal conductivity $\lambda_{\text {eff }}$ in BHE may vary up to $10 \%$ from the value determined from tests [15]. The influence of atmospheric air on the TRT results depends on the length of the BHE's connection to the apparatus and its thermal insulation (Figure 3).

TRT was developed mostly in Sweden [16]. A TRT is an indirect (in-situ) measurement method, which is the simplest and most exact way to determine precise thermal properties [17]. Thermal response tests were first suggested at an international conference in Stockholm [18]. A simple system was suggested, in which thermal energy at constant heating power was injected into a BHE while the BHE temperature was measured. Thermal response tests with mobile measurement equipment were first introduced in Sweden and USA in 1995. Since then, the method has developed and spread to several other countries in North America and Europe [17].

Until now, several studies regarding TRT have been conducted, e.g., [19-23]. Multiple modifications have been proposed, e.g., [24-28]. Traditional TRT applies a constant heating power to the pumped heat carrier [29]. The newer method, which holds the outflow heat carrier at a constant temperature, was shown to have many benefits, including shortening the test time and improving the operating constance and test exactness [30]. TRT can also be conducted numerically by simulating it in mathematical models [3,31,32].

Increasingly, the literature mentions the use of old, decommissioned boreholes, mainly oil wells $[33,34]$. The development of deep BHE installations reduces the cost of internal, heat insulating pipe column [35]. So far, there is no information in the literature about the implementation of TRT in a deep borehole. 
The purpose of this article is to determine the effect of temperature measurement frequency during the TRT on its results. Temperature measurements, as well as the measurement of other parameters during the test, e.g., differential pressure [36], can be recorded at different frequencies (averaged). The article analyzes how it affects the calculated value of effective thermal conductivity $\lambda_{\text {eff }}$ in BHE, which is a basic parameter determined during TRT.

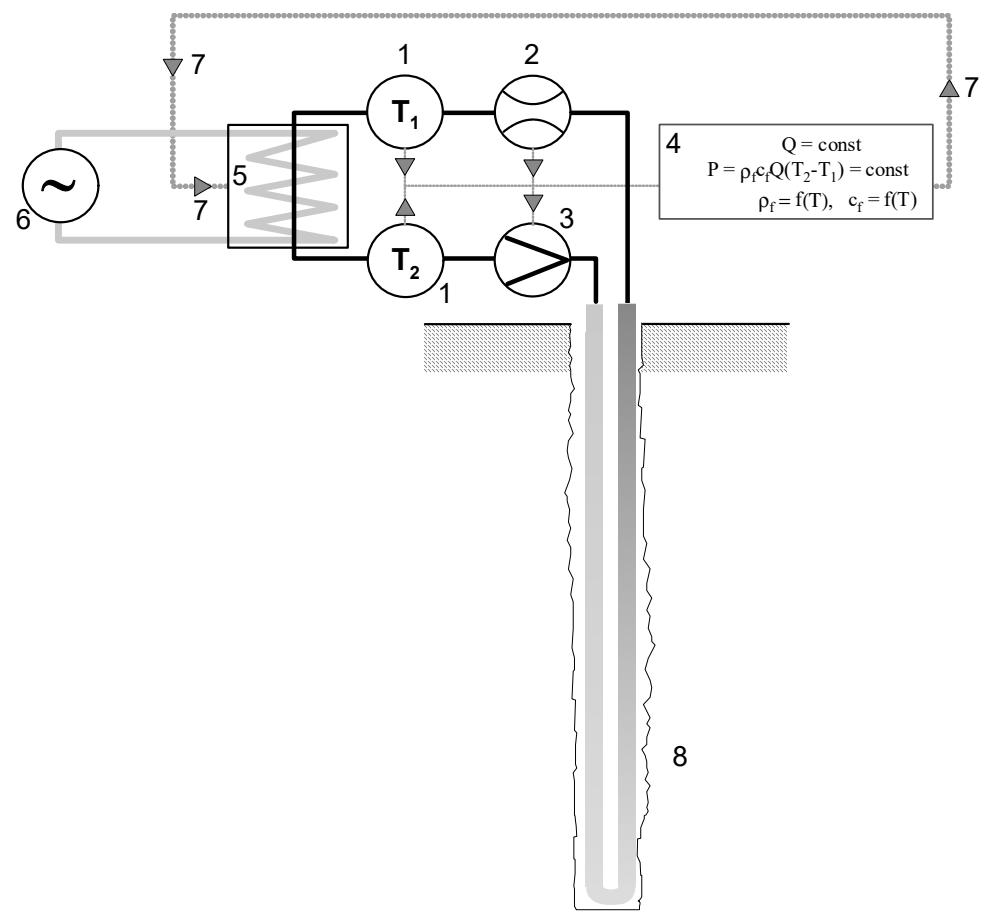

Figure 1. Schematic of thermal response test devices and operation. Legend: 1 -thermometer with absolute error $0.1{ }^{\circ} \mathrm{C}$, 2-flowmeter, 3-pump, 4-control computer (stabilization of thermal power and record the data), 5-set of heaters, 6 -current source, 7-heater control signal, 8-borehole heat exchanger, $\mathrm{Q}$ - flow rate of heat carrier, $\mathrm{P}$ - heat flow rate (power), $\mathrm{T}_{1}$-temperature of heat carrier (outflow from BHE), $\mathrm{T}_{1}$ - temperature of heat carrier (inflow to BHE), $\rho_{\mathrm{f}}=\mathrm{f}(\mathrm{T})$ - density of heat carrier as a function of temperature, $c_{f}=f(T)$-specific heat of heat carrier as a function of temperature.

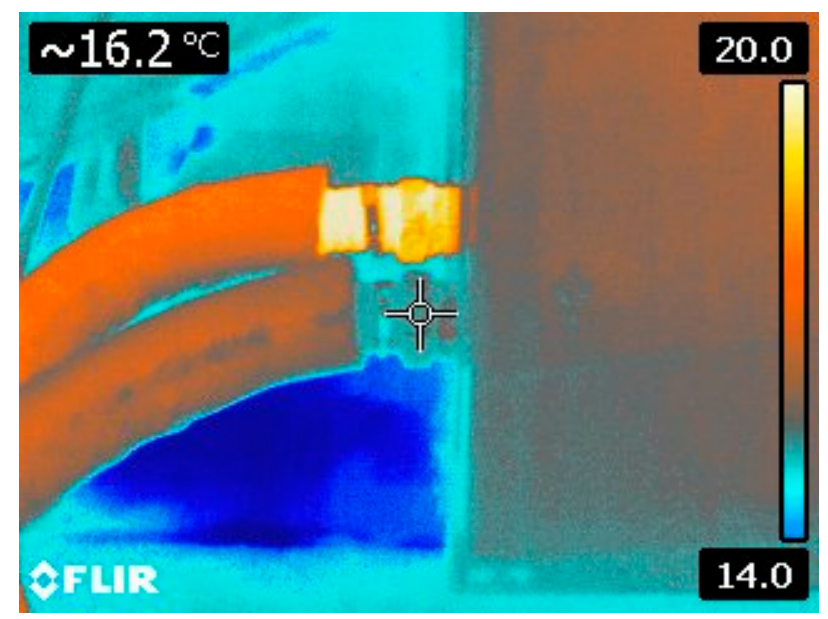

Figure 2. Thermogram of the borehole heat exchanger (BHE) connection to the thermal response tests (TRT) apparatus. 


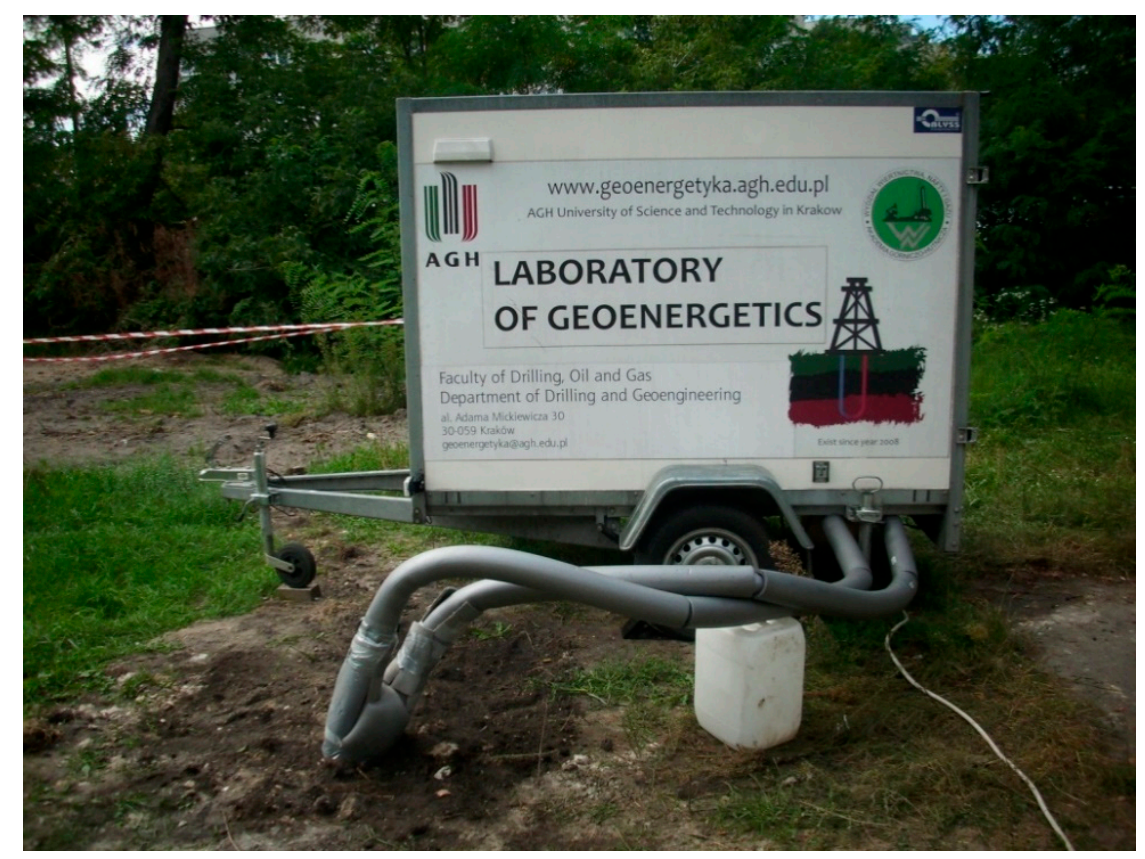

Figure 3. Thermal response test apparatus and its connection to the BHE.

Effective thermal conductivity $\lambda_{\text {eff }}$ in BHE is not the same value like weighted average thermal conductivity of geological layers $\lambda$. Difference between $\lambda_{\text {eff }}$ and $\lambda$ is due to method imperfections. Basic TRT operational parameters are heating power and heat carrier flow rate. That values determine effective thermal conductivity $\lambda_{\text {eff }}$ in BHE.

Different values of $\lambda_{\text {eff }}$ are also observed in various BHE constructions when the geological condition is the same. Not only borehole thermal resistance $R_{b}$ changes with various BHE constructions. One of the most important reasons are heat exchange area and velocity of heat carrier.

In the paper, only values of $\lambda_{\text {eff }}$ in the function of measurement frequency are analyzed. Additional results are the comparison of values of $\lambda_{\text {eff }}$ in different BHEs of Geoenergetics Laboratory.

The paper includes mathematical background of TRT. The described method is a classical/traditional method of effective thermal conductivity $\lambda_{\text {eff }}$ in the BHE calculation. Next is the description of three different BHEs of Laboratory of Geoenergetics located at the Department of Drilling, Oil and Gas AGH UST. Next paragraph shows the results of TRT made on the BHEs. Interpretation of the results by different temperature measurement frequency during the TRT is described.

Many different commercial TRTs results are shown. On the basis of TRT data, the effect of frequency averaging of TRT results was determined. The paper finishes with conclusions and references.

\section{Thermal Response Test}

Thermal response test is based on Fourier's generally known differential heat conduction equation, which in cylindrical coordinates is as follows [37]:

$$
\frac{\partial^{2} \mathrm{~T}}{\partial \mathrm{r}^{2}}+\frac{1}{\mathrm{r}} \frac{\partial \mathrm{T}}{\partial \mathrm{r}}=\frac{\rho \mathrm{C}_{\mathrm{p}}}{\lambda} \frac{\partial \mathrm{T}}{\partial \mathrm{t}}
$$

where:

$\rho$-density of the medium, $\mathrm{kg} / \mathrm{m}^{3}$,

$\mathrm{c}_{\mathrm{p}}$ - specific heat of the ground, $\mathrm{J} /(\mathrm{kgK})$,

$\lambda$-thermal conductivity of the ground, $\mathrm{W} /(\mathrm{mK})$,

$\mathrm{T}$-temperature, $\mathrm{K}$, 
t-time, s,

$\mathrm{r}-$ radius, $\mathrm{m}$.

Using the method proposed for the Theis equation in hydrogeology [38] to solve this type of differential equation, the substitution was used:

$$
\mathrm{u}=\frac{\mathrm{r}^{2} \rho \mathrm{C}_{\mathrm{p}}}{4 \mathrm{t} \lambda}
$$

and

$$
\rho \mathrm{C}_{\mathrm{p}}=\frac{\lambda}{\alpha}
$$

which is

$$
\mathrm{u}=\frac{\mathrm{r}^{2}}{4 \alpha \mathrm{t}}
$$

After appropriate transformations, Equation (1) takes the form of:

$$
\mathrm{u} \frac{\partial^{2} \mathrm{~T}}{\partial \mathrm{u}^{2}}+(1+\mathrm{u}) \frac{\partial \mathrm{T}}{\partial \mathrm{u}}=0
$$

After a series of transformations, a mathematical relationship is obtained:

$$
\mathrm{T}(\mathrm{r}, \mathrm{t})=\mathrm{T}_{0}+\frac{\mathrm{q}}{\mathrm{k} \pi \lambda} \int_{\frac{\mathrm{r}^{2}}{4 \alpha \mathrm{t}}}^{\infty} \frac{\mathrm{e}^{-\mathrm{x}}}{\mathrm{x}} \mathrm{dx}
$$

where:

$\mathrm{q}$ - unit heat transfer coefficient of the BHE, $\mathrm{W} / \mathrm{m}$,

$\mathrm{T}_{0}$-initial temperature in the BHE, $\mathrm{K}$.

Formula 6 is the basic equation on which the interpretation of the thermal response tests of the borehole heat exchangers is based. For a long time period further solution is possible. In the evaluations made of German TRTs, the minimum duration criterion as noted by [39] proved helpful:

$$
\mathrm{t}_{\min }=\frac{5 \cdot \mathrm{r}_{\mathrm{b}}^{2}}{\alpha}
$$

with $t_{\min }$ - lower time limit of data to be used for analysis and $r_{b}$-borehole radius.

Considering the integral of the exponential function further:

$$
\int_{u}^{\infty} \frac{e^{-x}}{x} d x
$$

it can be represented using the additive property of the integral relative to the integration interval and the integral function as follows:

$$
\int_{u}^{\infty} \frac{\mathrm{e}^{-\mathrm{x}}}{\mathrm{x}} \mathrm{dx}=-\left[\int_{0}^{1}\left(1-\mathrm{e}^{-\mathrm{x}}\right) \frac{\mathrm{dx}}{\mathrm{x}}-\int_{1}^{\infty} \frac{\mathrm{e}^{-\mathrm{x}}}{\mathrm{x}} \mathrm{dx}+\int_{1}^{\mathrm{u}} \frac{\mathrm{dx}}{\mathrm{x}}-\int_{0}^{\mathrm{u}}\left(1-\mathrm{e}^{-\mathrm{x}}\right) \frac{\mathrm{dx}}{\mathrm{x}}\right]
$$

By replacing the values of the integral with its approximate value, a relation is eventually obtained:

$$
\mathrm{T}(\mathrm{r}, \mathrm{t}) \cong \mathrm{T}_{0}+\frac{\mathrm{q}}{4 \pi \lambda}\left[\ln \left(\frac{4 \alpha \mathrm{t}}{\mathrm{r}^{2}}\right)-\gamma\right]
$$


Test results show the relation between the heat carrier temperature and time. This allows for calculation of the effective thermal conductivity $\lambda_{\text {eff }}$ according to the formula [29]:

$$
\lambda_{\mathrm{ef}}=\frac{\mathrm{P}}{4 \cdot \pi \cdot \mathrm{k} \cdot \mathrm{H}}
$$

where:

$\mathrm{P}-$ mean heating power during the TRT, $\mathrm{W}$,

$\mathrm{H}$-depth of the borehole heat exchanger, $\mathrm{m}$,

$\mathrm{k}$ - the slope of the trend line-a straight line determined as the ratio of the mean temperature to the logarithm of the natural test time.

According to the mathematical model, effective thermal conductivity is identical to the thermal conductivity of the medium (rock mass). In reality, this value also depends on:

- the design of the borehole heat exchanger,

- $\quad$ TRT parameters, and

- how the measurement results are averaged, as shown in this article. Its aim is to show the diversity of the final measurement results, which can be regarded as a manifestation of their uncertainty.

\section{The Scope of the Conducted Research}

Laboratory of Geoenergetics located at the Department of Drilling, Oil and Gas AGH UST contains borehole heat exchangers of different designs [4]. Three of them were subjected to the described research, short characteristics of which are given in Table 1. The location of aforementioned BHEs is shown in Figure 4. Similar studies for various BHE designs have already been described in literature $[1,12,26]$.

Table 1. Characteristics of the researched borehole heat exchangers belonging to the Laboratory of Geoenergetics, Department of Drilling, Oil and Gas AGH UST [40].

\begin{tabular}{|c|c|c|}
\hline BHE No. & Characteristics of the BHE Construction & Symbol \\
\hline BHE-1 & $\begin{array}{l}\text { Depth } 76.4 \mathrm{~m} \text {, coaxial design (pipe in pipe). Outer diameter of the outer pipe } \\
\text { equals } 90 \mathrm{~mm} \text {, wall thickness } 5.4 \mathrm{~mm} \text {. Outer diameter of the inner pipe is } 40 \\
\mathrm{~mm} \text {, with wall thickness } 2.4 \mathrm{~mm}\end{array}$ & \\
\hline BHE-3 & $\begin{array}{l}\text { Depth } 76.4 \mathrm{~m} \text {, design consisting of a single U-tube. Distance between pipe } \\
\text { axes equals } 80 \mathrm{~mm} \text {. Outer diameter of the exchanger pipes is } 40 \mathrm{~mm} \text {. Wall } \\
\text { thickness } 2.4 \mathrm{~mm} \text {. Heat-improved sealing material (thermocem) with heat } \\
\text { conduction } \lambda=2.0 \mathrm{~W} /(\mathrm{mK})\end{array}$ & \\
\hline BHE-5 & $\begin{array}{l}\text { Depth } 76.4 \mathrm{~m} \text {, system with double U-tube. Distance between the pipe axes is } \\
70 \mathrm{~mm} \text {. Outer diameter of the pipes equals } 32 \mathrm{~mm} \text {, wall thickness } 2.4 \mathrm{~mm}\end{array}$ & \\
\hline
\end{tabular}

The study consisted of determining the effective thermal conductivity $\lambda_{\text {eff }}$ in the borehole, which depended primarily on the thermal conductivity of the rocks in the lithological profile. Drilled lithological profile is presented in Table 2 [40]. 

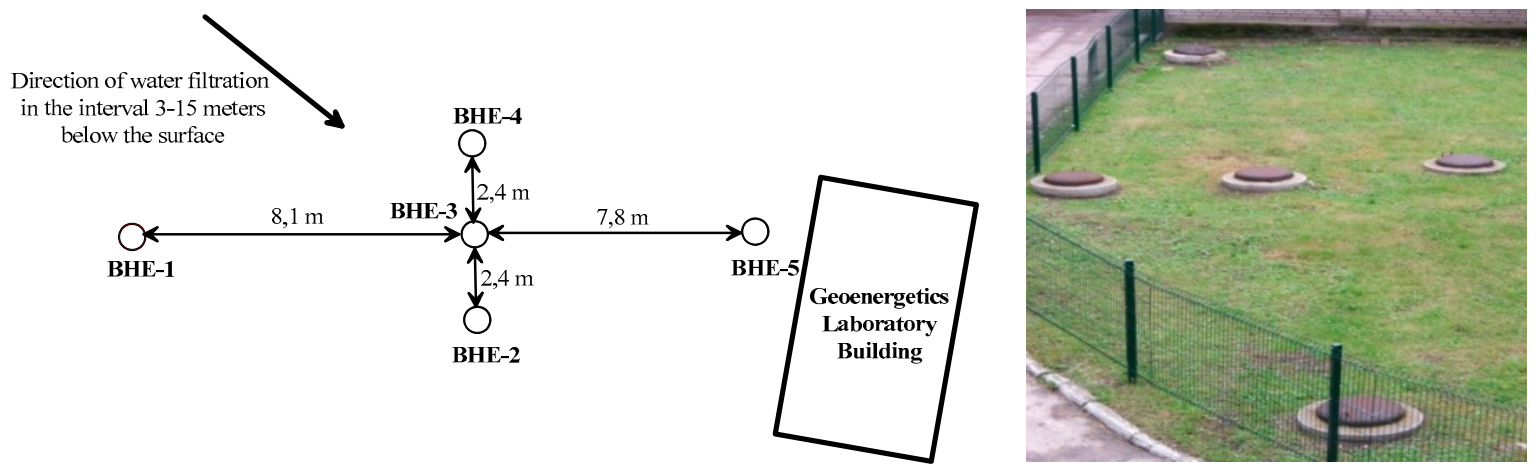

Figure 4. Layout of the borehole heat exchanger field in the Laboratory of Geoenergetics, Department of Drilling, Oil and Gas AGH UST. BHE-1 is a coaxial system, BHE-2, BHE-3, and BHE-4 are boreholes with a single U-pipe design and various sealing, BHE-5 has a double U-tube design [3].

Values of the thermal conductivity of rocks were determined based on literature data [12,41,42].

The measuring apparatus (Figure 3) consisted of two modules together with a computer controlling and recording data (Figure 5). It corresponds to the schematic of thermal response test devices and operation from Figure 1. The first module included electric heaters and a circulation pump, the second consisted of flow meters and thermometers. The computer program recorded all data necessary to calculate subsequent parameters. These data included the exact date and time from the start of the measurement, the temperature of the heating agent at the inflow and outflow of the borehole heat exchanger, the outside temperature, the difference in pressure at the inflow and outflow of the borehole heat exchanger, and the accumulated electricity.

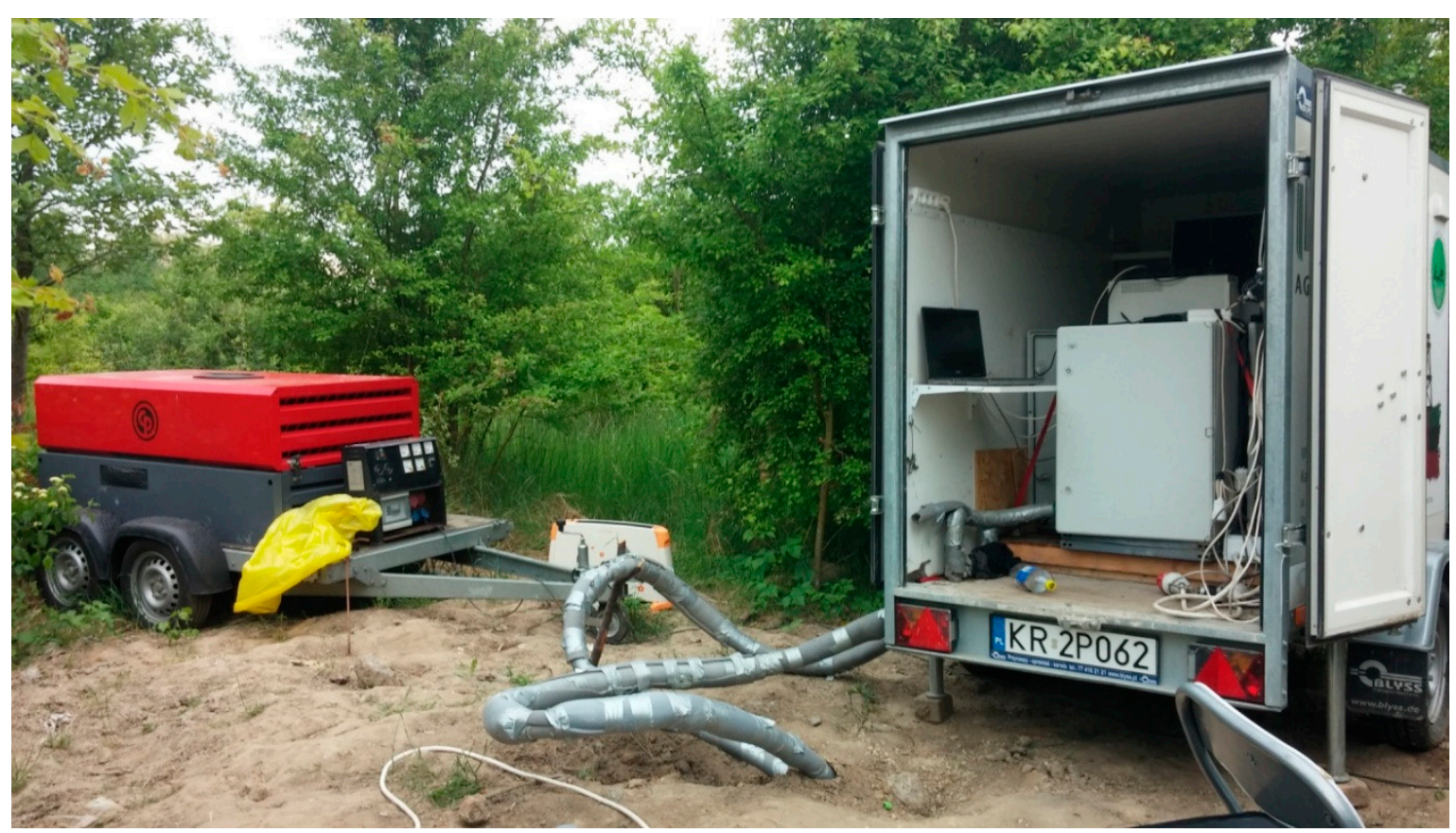

Figure 5. Modules of the TRT apparatus together with a power generator (corresponds to Figure 1).

Measurement results were recorded every second with time stabilization provided by the computer processor. The precision of the measurement time recording was high and equaled 0.2 milliseconds. Temperature measurements were performed with thermometers with an accuracy class of $1 \%$. Flow meters had an average accuracy of $5 \%$, up to $2 \%$ in an optimal operating range. 
Table 2. Stratigraphic lithological profile of the LG-2a borehole together with selected thermal parameters of rocks [40].

\begin{tabular}{|c|c|c|c|c|c|c|c|}
\hline $\begin{array}{l}\text { No. of } \\
\text { Layer }\end{array}$ & $\begin{array}{l}\text { Top of the } \\
\text { Layer, } \\
\text { m }\end{array}$ & $\begin{array}{c}\text { Bottom of } \\
\text { the Layer, } \\
\mathrm{m}\end{array}$ & $\begin{array}{c}\text { Thicness of } \\
\text { the Layer, } \\
\text { m }\end{array}$ & Lithology & Stratigraphy & $\begin{array}{c}\text { Thermal } \\
\text { Conductivity, } \lambda, \\
\mathbf{W} \cdot \mathbf{m}^{-1} \mathbf{K}^{-1}\end{array}$ & $\begin{array}{c}\text { Volumetric Heat } \\
\text { Capacity, } c_{v}, \\
\text { MJ.m } \mathbf{m}^{-3} \mathbf{K}^{-1}\end{array}$ \\
\hline 1 & 0.0 & 2.2 & 2.2 & Anthropogenic soil (dark gray bank with debris) & \multirow{5}{*}{$\begin{array}{c}\text { Quaternary (Pleistocene, } \\
\text { Holocene) }\end{array}$} & 1.600 & 2.000 \\
\hline 2 & 2.2 & 2.6 & 0.4 & Silt (gray soil) & & 1.600 & 2.200 \\
\hline 3 & 2.6 & 4.0 & 1.4 & Fine and dusty sand, slightly argillaceous & & 1.000 & 2.000 \\
\hline 4 & 4.0 & 6.0 & 2.0 & Fine sand & & 1.200 & 2.500 \\
\hline 5 & 6.0 & 15.0 & 9.0 & All-in aggregate and gravel & & 1.800 & 2.400 \\
\hline 6 & 15.0 & 30.0 & 15.0 & Gray loam & \multirow{2}{*}{ Tertiary (Miocene) } & 2.200 & 2.300 \\
\hline \multirow[t]{2}{*}{7} & 30.0 & 78.0 & 48.0 & Gray shale & & 2.100 & 2.300 \\
\hline & & & & & Weighted average & 2.039 & 2.309 \\
\hline
\end{tabular}


Data from TRT were obtained by summing all the records from every second and dividing by their number every $1 \mathrm{~min}, 10 \mathrm{~min}$, and $1 \mathrm{~h}$, which is a classic arithmetic mean. It was originally assumed that the median was an average value, but such averaging was more time consuming. Due to the very small differences between the median and the arithmetic mean, and a significantly shorter time of determining the latter estimator, it was decided to calculate the arithmetic mean. Data recording on the disc was carried out with precision to two decimal places.

\section{Measurement Results}

Presented results include measurements for three boreholes of the Laboratory of Geoenergetics (number 1, 3, and 5). Each time, the test was preceded by a 24-h rinsing period without heating the heat carrier in order to effectively vent the system and equalize the temperature in the rock mass. In the next stage, heaters were started with a set power and worked for $100 \mathrm{~h}$. This time ensured the stabilization of the effective thermal conductivity value, which is a basic parameter in the BHE measurements. On this basis, the ability of the rock mass to dissipate/store heat could be determined. The assumed heating power with which the heaters heated the working fluid was $2.8 \mathrm{~kW}$. The heat carrier flow capacity was $20 \mathrm{dm}^{3} / \mathrm{min}$.

Effective thermal conductivity was calculated from Formula 10. The slope factor of the straight line $\mathrm{k}$ was determined with Microsoft Excel using the REGLINP function. It uses the least squares method.

The distribution of the average temperature in the graphs according to the time intervals of data averaging (every $1 \mathrm{~min}, 10 \mathrm{~min}$, and $1 \mathrm{~h}$ ) are shown in Figures 6-11. Figure 6 shows the measurement results for the borehole No. 1, with the measurement data averaging every $1 \mathrm{~h}$. Figure 7 shows the same relationship but in a semi-logarithmic plot. Figure 8 shows the measurement results for borehole No. 3, with the measurement data averaging every $10 \mathrm{~min}$. Figure 9 shows the same relationship but in a semi-logarithmic plot. Figure 10 shows the measurement results for borehole No. 5 with the measurement data averaging every $1 \mathrm{~min}$. Figure 11 shows the same relationship but in a semi-logarithmic plot.

The curves are so wobbly (identically wobbly) because of no ideal thermal insulation. As shown in Figure 5, thermal insulation of pipes is used. Figure 2 (thermogram) shows the need for even better thermal insulation.

Every graph (Figures 6-11) was based on the same TRT. The precision of the temperature time recording with the use was the current computer science standard, equal to 0.2 milliseconds. Different results were based only on different averaging intervals.

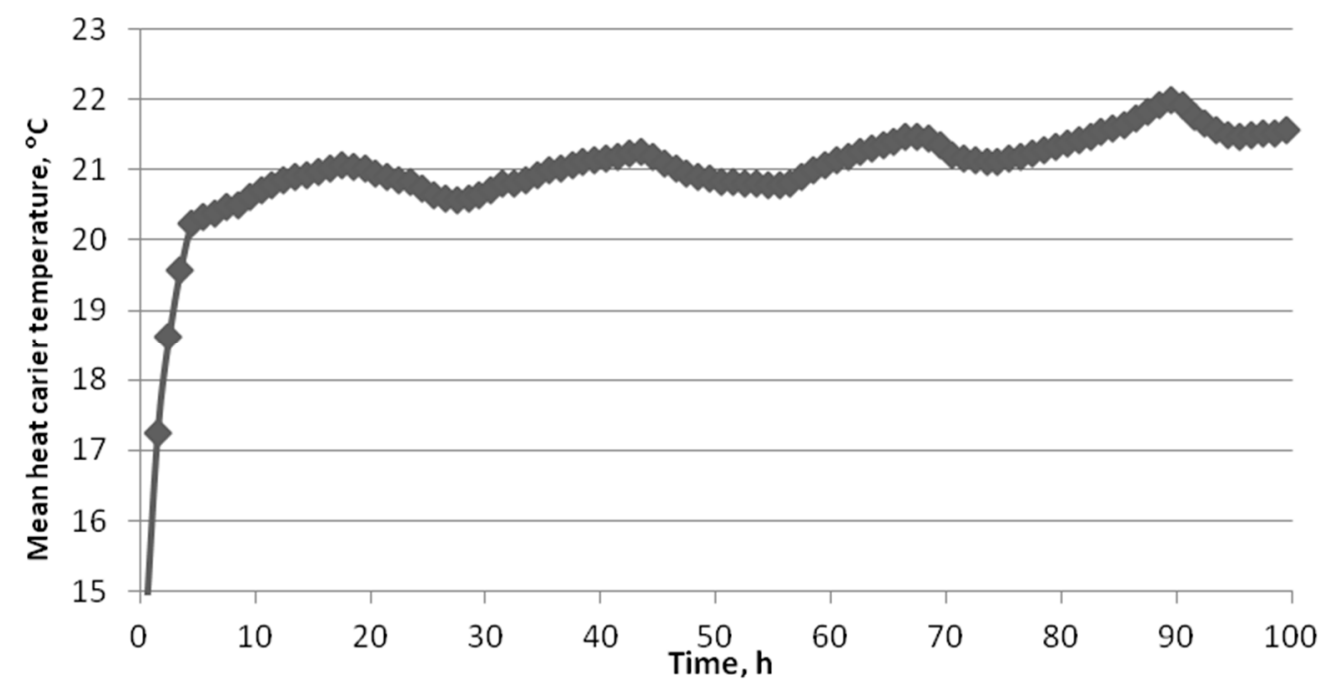

Figure 6. TRT results with the measurement data averaging every $1 \mathrm{~h}$. 


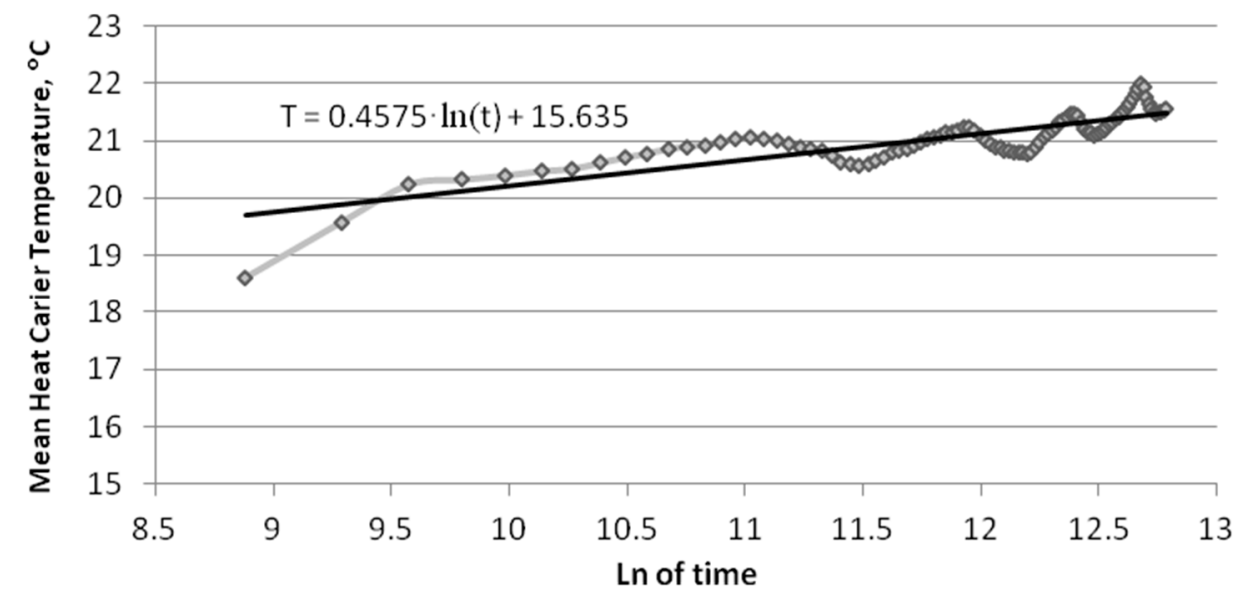

Figure 7. TRT results with the measurement data averaging every $1 \mathrm{~h}$ in a semi-logarithmic plot, together with the linear regression equation.

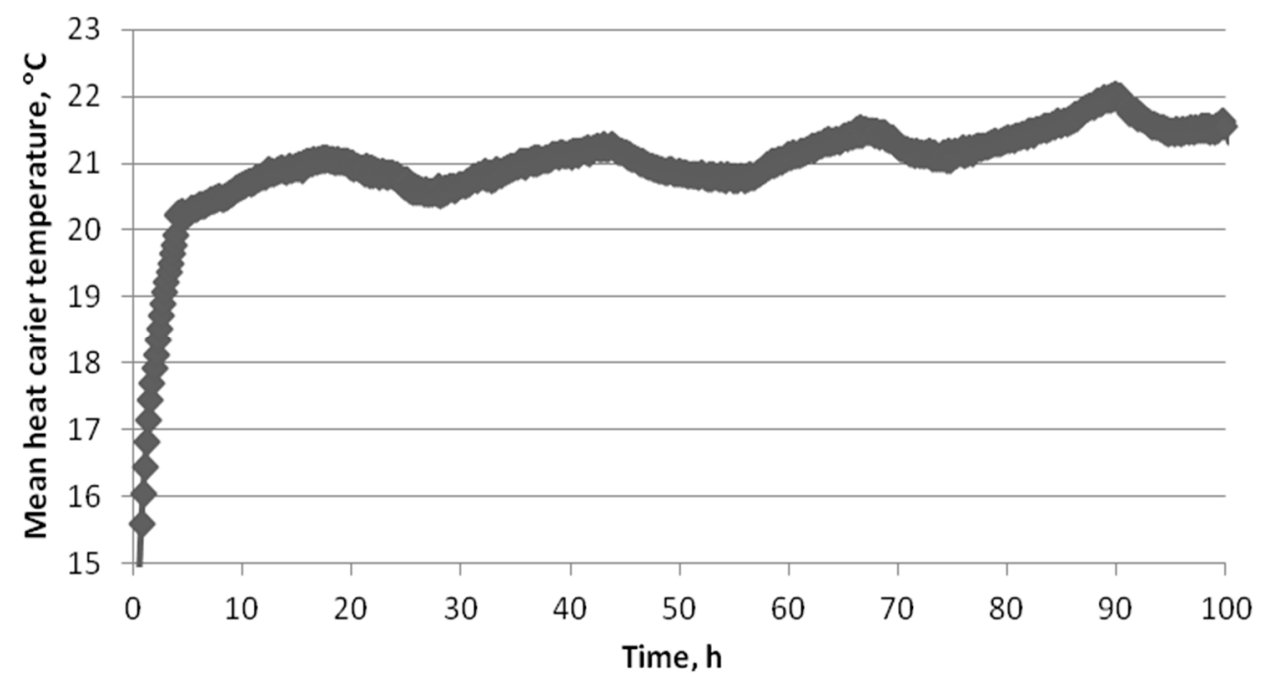

Figure 8. TRT results with the measurement data averaging every $10 \mathrm{~min}$.

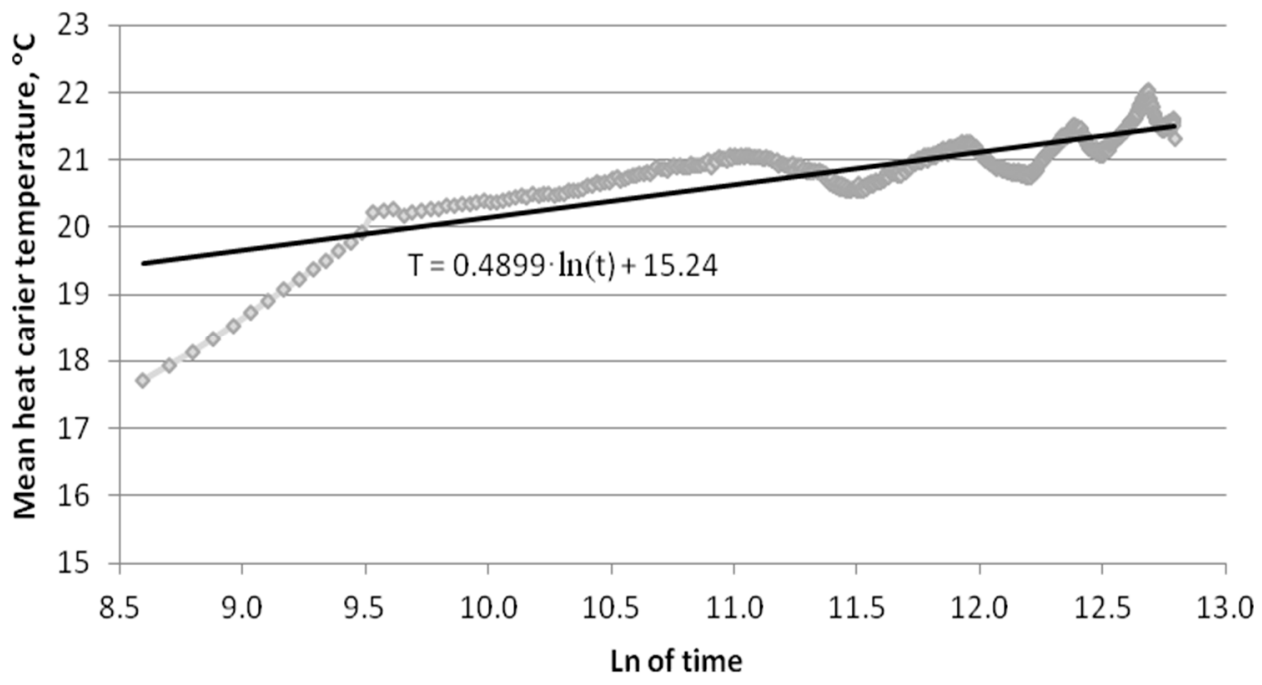

Figure 9. TRT results with the measurement data averaging every $10 \mathrm{~min}$ in a semi-logarithmic plot, together with the linear regression equation. 


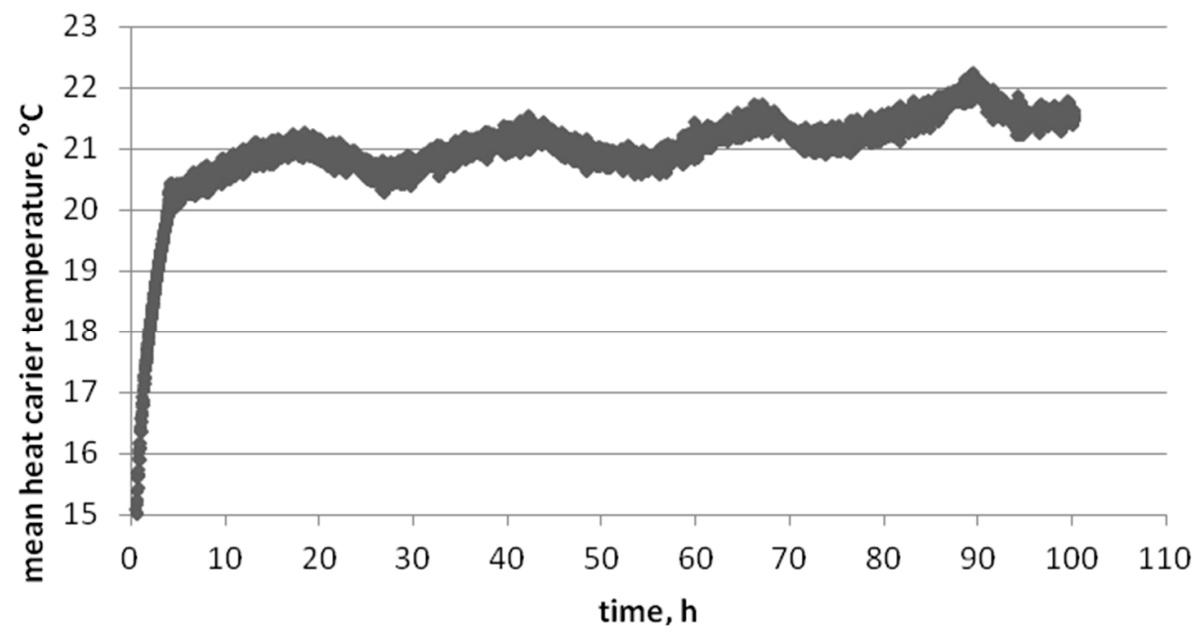

Figure 10. TRT results with the measurement data averaging every $1 \mathrm{~min}$.

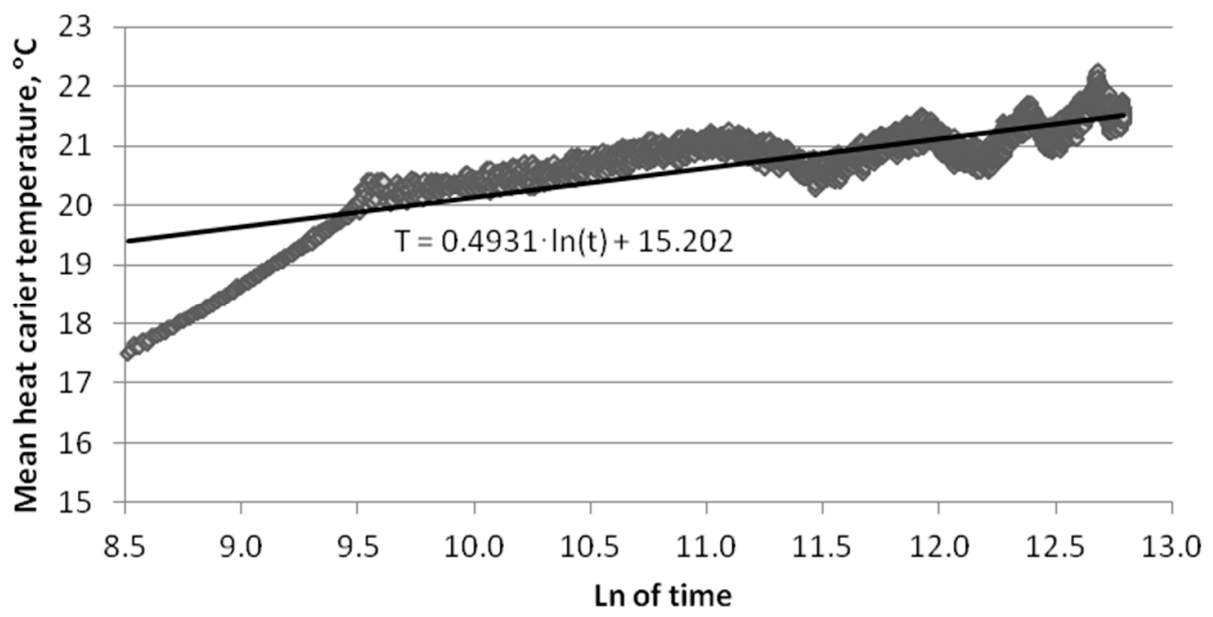

Figure 11. TRT results with the measurement data averaging every $1 \mathrm{~min}$ in a semi-logarithmic plot, together with the linear regression equation.

\section{Interpretation of TRT Results}

Values of the effective thermal conductivity $\lambda_{\text {eff }}$ based on the conducted thermal response tests are presented in Table 3. Start time of calculation of $\lambda_{\text {eff }}$ corresponded with Equation (7). End time corresponded with the end of heating time (end of TRT). The highest values are marked in red and the lowest in green. There is no correlation to be seen from the presented results.

Table 3. Effective thermal conductivity values in BHEs (highest values in red, lowest in green), taking into consideration sensors uncertainty the values of $\lambda_{\text {eff }}$ has uncertainty equals $\pm \Delta \lambda_{\text {eff }}=0.032 \mathrm{Wm}^{-1} \mathrm{~K}^{-1}$.

\begin{tabular}{|c|c|c|c|c|}
\hline BHE No. & $\begin{array}{c}\text { Value of } \lambda_{e f f} \text { with } \\
\text { Interval of } 1 \mathrm{~min}, \\
\mathrm{Wm}^{-1} \mathrm{~K}^{-1}\end{array}$ & $\begin{array}{l}\text { Value of } \lambda_{\text {eff }} \text { with } \\
\text { Interval of } 10 \mathrm{~min} \text {, } \\
\mathrm{Wm}^{-1} \mathrm{~K}^{-1}\end{array}$ & $\begin{array}{c}\text { Value of } \lambda_{e f f} \text { with } \\
\text { Interval of } 1 \mathrm{~h}, \\
\mathrm{Wm}^{-1} \mathrm{~K}^{-1}\end{array}$ & $\begin{array}{c}\text { Volatility * of the } \\
\lambda_{\text {eff }} \text { Value, } \\
\mathbf{W m}^{-1} \mathbf{K}^{-1}\end{array}$ \\
\hline BHE-1 & 1.585 & 1.613 & 1.610 & 0.028 \\
\hline BHE-3 & 1.540 & 1.539 & 1.529 & 0.011 \\
\hline BHE-5 & 1.516 & 1.515 & 1.579 & 0.064 \\
\hline
\end{tabular}

* Maximum value (red) minus minimum one (green).

The variability of the heat conduction value for borehole No. 1 is $0.028 \mathrm{Wm}^{-1} \mathrm{~K}^{-1}$, for borehole No. 3 it is $0.011 \mathrm{Wm}^{-1} \mathrm{~K}^{-1}$, and for borehole No. 5 it is $0.064 \mathrm{Wm}^{-1} \mathrm{~K}^{-1}$. The relative error resulting from the method of averaging equals $1.74 \%, 0.71 \%$, and $4.05 \%$, respectively. 
Table 4 shows different statistics. As presented, the volatility factor is less than $2.5 \%$. With the same geology (the distance between the boreholes is shown in Figure 4), the value of this factor is quite high. This is due to the fact that the effective thermal conductivity $\lambda_{\text {eff }}$ is not the same as the average thermal conductivity of the rock mass $\lambda$, which, according to Table 2, equals $2.039 \mathrm{Wm}^{-1} \mathrm{~K}^{-1}$, which is the weighted average conductivity according to literature data. The accuracy results from averaging. Literature data is based mostly on the measuring dry samples. Is-situ measurements are not applicable in the presented research, because coring is too expensive. Real values of rocks heat conductivity in rock mass varies in high range. The reason is, for example, saturation, underground water filtration, and conductivity anisotropy.

Table 4. Statistics of effective thermal conductivity $\lambda_{\text {eff }}$ values in BHEs.

\begin{tabular}{cccc}
\hline BHE No. & $\begin{array}{c}\text { Average } \lambda_{\text {eff, }} \\
\mathbf{W ~ m}^{\mathbf{- 1}} \mathbf{K}^{-\mathbf{1}}\end{array}$ & $\begin{array}{c}\text { Standard Deviation } \boldsymbol{\lambda}_{\text {eff, }} \\
\mathbf{W m}^{-\mathbf{1}} \mathbf{K}^{\mathbf{- 1}}\end{array}$ & $\begin{array}{c}\text { Coefficient of Variation, } \\
\mathbf{\%}\end{array}$ \\
\hline BHE-1 & 1.603 & 0.015 & 0.94 \\
BHE-3 & 1.536 & 0.006 & 0.39 \\
BHE-5 & 1.537 & 0.037 & 2.40 \\
\hline
\end{tabular}

Table 4 shows that the most advantageous design is the coaxial BHE, while single and double U-pipe exchangers are identical. The basic indicator that shows BHE quality is borehole thermal resistance $R_{b}$. It will be described in a separate paper. The same influence on BHE quality also shows effective thermal conductivity $\lambda_{\text {eff. }}$ This value depends to some extent on the heat transfer from the carrier to the pipes. The heat penetration, however, also depends on the heat carrier's flow velocity. Heat penetration through the inner pipe and outer pipe is also of a different nature with U-pipe BHEs constructions.

For the latter case, the highest value of the coefficient of variation can be observed for different methods of the measurement results averaging. The value closest to the theoretical $\lambda=2.039$ was measured in BHE-1, but it is not necessary that the effective thermal conductivity $\lambda_{\text {eff }}$ measured will match an average textbook rock mass thermal conductivity $\lambda$.

The same values are shown on below diagrams. For BHE-1 in Figure 12, for BHE-3 in Figure 13 and for BHE-5 in Figure 14. The number of significant digits results from averaging. One digit less gives the same averages in one case.

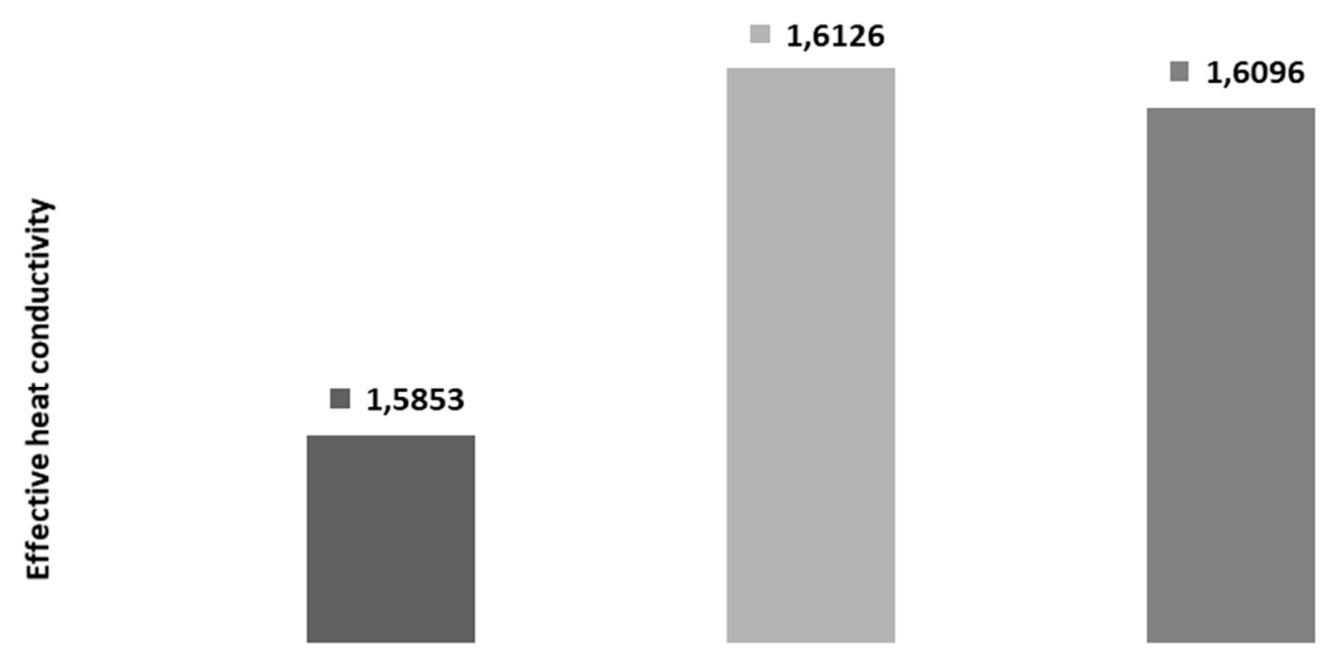

Time interval of averaging measurements

Figure 12. Effective thermal conductivity $\lambda_{\text {eff }}$ depending on time interval for BHE-1 (coaxial). 


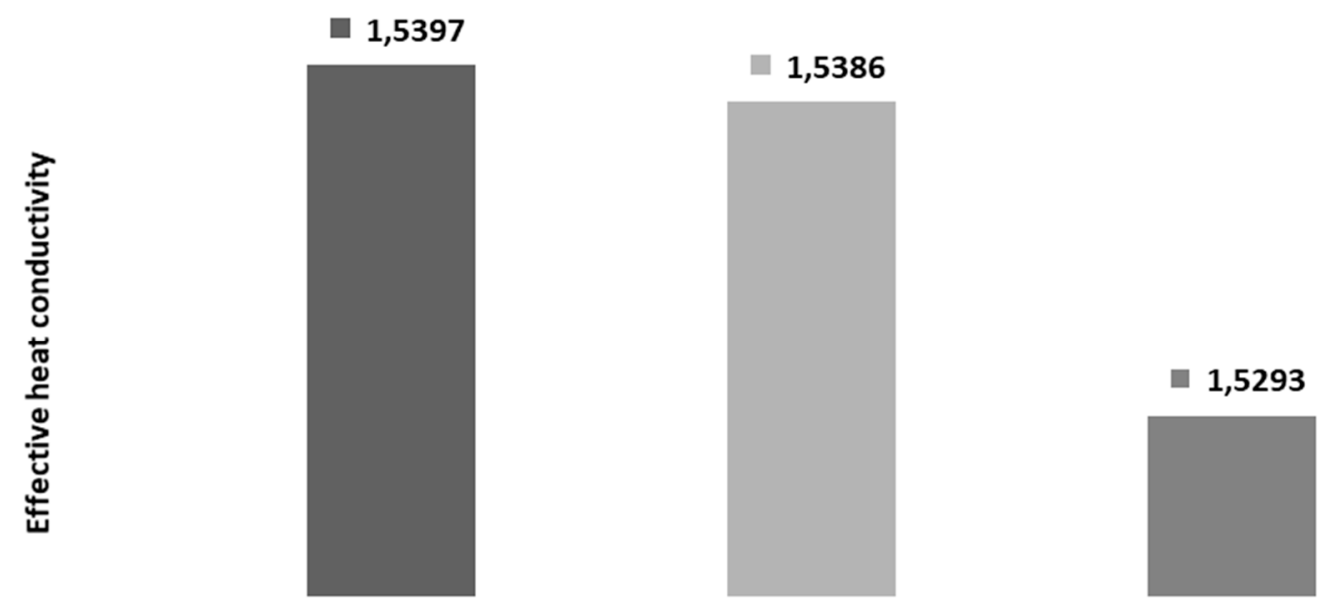

Time interval of averaging measurements

Figure 13. Effective thermal conductivity $\lambda_{\text {eff }}$ depending on time interval for BHE-3 (single U-pipe).

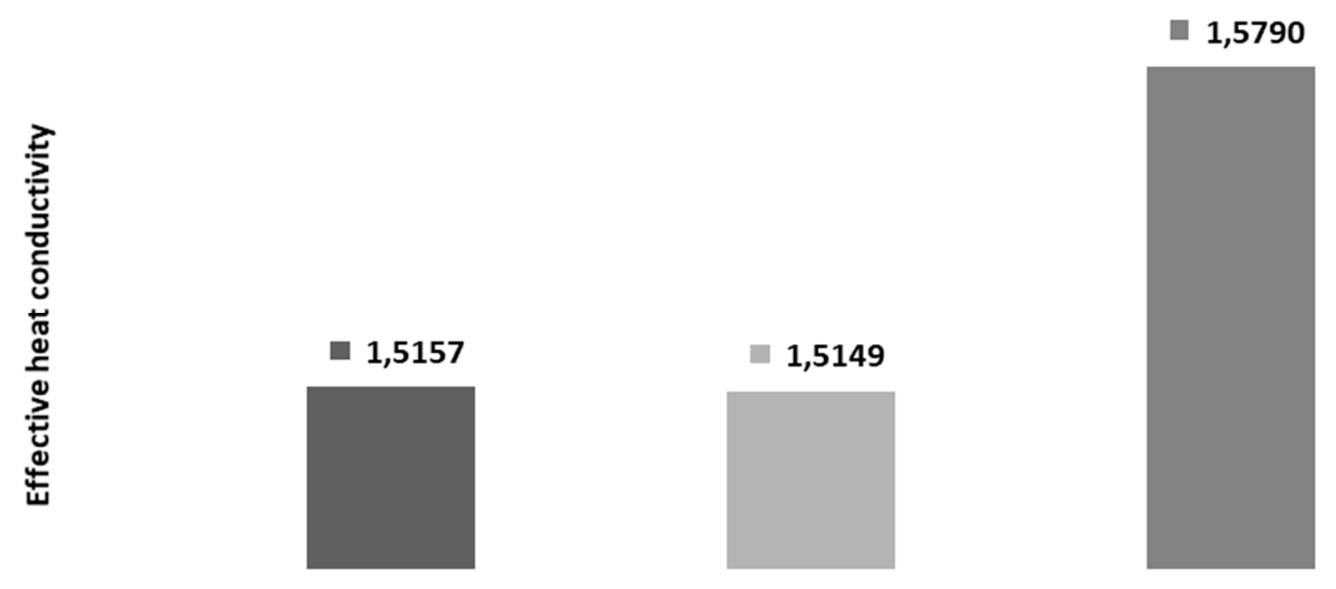

\section{Time interval of averaging measurements}

Figure 14. Effective thermal conductivity $\lambda_{\text {eff }}$ depending on time interval for BHE-5 (double U-pipe).

The diagrams of effective thermal conductivity $\lambda_{\text {eff }}$ for individual heat exchangers depending on the time interval of measurement averaging, illustrate the differences between the values obtained for different boreholes with the same parameters, such as the flow rate of the heat carrier and the set heating power. For the sake of a more thorough statistical analysis on the impact of measurement averaging on TRT results, data from commercial thermal response tests were used [43]. Borehole and test data, as well as the interpretation results, are presented in Tables 5-9. 
Table 5. Parameters of the tested exchangers, with the interval of every $1 \mathrm{~min}$.

\begin{tabular}{|c|c|c|c|c|c|c|}
\hline $\begin{array}{l}\text { Location of the } \\
\text { Exchanger }\end{array}$ & $\begin{array}{c}\text { Average Heating } \\
\text { Power during TRT, } \mathrm{W}\end{array}$ & $\begin{array}{c}\text { Standard Deviation } \\
\text { of Heating Power, } \mathrm{W}\end{array}$ & $\begin{array}{l}\text { Coefficient of } \\
\text { Variation, } \%\end{array}$ & $\begin{array}{l}\text { Borehole } \\
\text { Depth, } \mathrm{m}\end{array}$ & $\begin{array}{c}\text { Average Unit } \\
\text { Heating Power, } \mathrm{W} / \mathrm{m}\end{array}$ & $\begin{array}{l}\text { Slope of the Regression Line in } \\
\text { a Semi-Logarithmic Plot }\end{array}$ \\
\hline Łódź & 6645 & 127.36 & 1.92 & 120 & 55.38 & 1.8632 \\
\hline Szczecin & 10,008 & 60.24 & 0.60 & 191 & 52.40 & 1.5816 \\
\hline Polkowice & 7800 & 24.52 & 0.31 & 153 & 50.98 & 1.8542 \\
\hline \multirow{2}{*}{ Rawa Mazowiecka } & 2509 & 26.03 & 1.04 & 48 & 52.27 & 1.7100 \\
\hline & 7009 & 56.61 & 0.81 & 140 & 50.06 & 1.4352 \\
\hline Kraków I & 7823 & 383.32 & 4.90 & 150 & 52.15 & 1.9694 \\
\hline Wolsztyn & 9523 & 86.99 & 0.91 & 200 & 47.62 & 2.1722 \\
\hline Gola Dzierżoniowska & 7014 & 226.90 & 3.23 & 150 & 46.76 & 1.2513 \\
\hline \multirow{2}{*}{ Żarów } & 6000 & 79.97 & 1.33 & 120 & 50.00 & 1.5873 \\
\hline & 5997 & 124.74 & 2.08 & 120 & 49.98 & 1.4193 \\
\hline Białystok & 4390 & 245.75 & 5.60 & 100 & 43.90 & 1.4745 \\
\hline Wrocław & 4072 & 141.12 & 3.47 & 133 & 30.62 & 1.4139 \\
\hline Kraków II & 4813 & 154.05 & 3.20 & 150 & 32.09 & 1.2354 \\
\hline Niepołomice & 4007 & 100.27 & 2.50 & 140 & 28.62 & 0.8564 \\
\hline Kraków III & 8892 & 288.36 & 3.24 & 200 & 44.46 & 1.8384 \\
\hline
\end{tabular}

Table 6. Parameters of the tested exchangers, with the interval of every $10 \mathrm{~min}$.

\begin{tabular}{|c|c|c|c|c|c|c|}
\hline $\begin{array}{l}\text { Location of the } \\
\text { Exchanger }\end{array}$ & $\begin{array}{c}\text { Average Heating } \\
\text { Power during TRT, } W\end{array}$ & $\begin{array}{l}\text { Standard Deviation } \\
\text { of Heating Power, W }\end{array}$ & $\begin{array}{l}\text { Coefficient of } \\
\text { Variation, \% }\end{array}$ & $\begin{array}{l}\text { Borehole } \\
\text { Depth, } \mathrm{m}\end{array}$ & $\begin{array}{c}\text { Average Unit } \\
\text { Heating Power, W/m }\end{array}$ & $\begin{array}{l}\text { Slope of the Regression Line } \\
\text { in a Semi-Logarithmic Plot }\end{array}$ \\
\hline Łódź & 6648 & 28.28 & 0.43 & 120 & 55.40 & 1.8463 \\
\hline Szczecin & 10,008 & 14.87 & 0.15 & 191 & 52.40 & 1.4713 \\
\hline Polkowice & 7799 & 38.83 & 0.5 & 153 & 50.97 & 1.8620 \\
\hline \multirow[b]{2}{*}{ Rawa Mazowiecka } & 2509 & 12.13 & 0.48 & 48 & 52.27 & 1.4534 \\
\hline & 7008 & 24.28 & 0.35 & 140 & 50.06 & 1.8801 \\
\hline Kraków I & 7824 & 68.32 & 0.87 & 150 & 52.16 & 2.0785 \\
\hline Wolsztyn & 9523 & 54.65 & 0.57 & 200 & 47.62 & 2.134 \\
\hline Gola Dzierżoniowska & 7014 & 39.13 & 0.56 & 150 & 46.76 & 1.2995 \\
\hline \multirow[b]{2}{*}{ Żarów } & 6000 & 39.06 & 0.65 & 120 & 50.00 & 1.4714 \\
\hline & 5998 & 73.58 & 1.23 & 120 & 49.98 & 1.4543 \\
\hline Białystok & 4387 & 137.96 & 3.15 & 100 & 43.87 & 1.3974 \\
\hline Wrocław & 4071 & 176.86 & 4.34 & 133 & 30.61 & 1.4834 \\
\hline Kraków II & 4813 & 121.38 & 2.52 & 150 & 32.09 & 1.2582 \\
\hline Niepołomice & 4007 & 158.25 & 3.95 & 140 & 28.62 & 0.8629 \\
\hline Kraków III & 8890 & 273.58 & 3.08 & 200 & 44.45 & 1.9976 \\
\hline
\end{tabular}


Table 7. Parameters of the tested exchangers, with the interval of every $60 \mathrm{~min}$.

\begin{tabular}{|c|c|c|c|c|c|c|}
\hline $\begin{array}{l}\text { Location of the } \\
\text { Exchanger }\end{array}$ & $\begin{array}{c}\text { Average Heating } \\
\text { Power during TRT, } W\end{array}$ & $\begin{array}{l}\text { Standard Deviation } \\
\text { of Heating Power, } \mathrm{W}\end{array}$ & $\begin{array}{l}\text { Coefficient of } \\
\text { Variation, \% }\end{array}$ & $\begin{array}{l}\text { Borehole } \\
\text { Depth, m }\end{array}$ & $\begin{array}{c}\text { Average Unit } \\
\text { Heating Power, W/m }\end{array}$ & $\begin{array}{l}\text { Slope of the Regression Line } \\
\text { in a Semi-Logarithmic Plot }\end{array}$ \\
\hline Łódź & 6636 & 106.70 & 1.61 & 120 & 55.30 & 1.8421 \\
\hline Szczecin & 10,009 & 4.01 & 0.04 & 191 & 52.40 & 1.8276 \\
\hline Polkowice & 7800 & 2.18 & 0.03 & 153 & 50.98 & 1.8430 \\
\hline \multirow{2}{*}{ Rawa Mazowiecka } & 2508 & 10.42 & 0.42 & 48 & 52.25 & 1.4979 \\
\hline & 7009 & 5.38 & 0.08 & 140 & 50.06 & 2.0205 \\
\hline Kraków I & 7794 & 14.71 & 0.19 & 150 & 51.96 & 2.2584 \\
\hline Wolsztyn & 9523 & 28.45 & 0.30 & 200 & 47.62 & 2.1623 \\
\hline Gola Dzierżoniowska & 7014 & 14.19 & 0.20 & 150 & 46.76 & 1.4956 \\
\hline \multirow{2}{*}{ Żarów } & 6000 & 17.29 & 0.29 & 120 & 50.00 & 1.593 \\
\hline & 5996 & 33.78 & 0.56 & 120 & 49.97 & 1.4702 \\
\hline Białystok & 4390 & 99.77 & 2.27 & 100 & 43.90 & 1.3912 \\
\hline Wrocław & 4077 & 227.82 & 5.59 & 133 & 30.65 & 1.484 \\
\hline Kraków II & 4810 & 102.54 & 2.13 & 150 & 32.07 & 1.3227 \\
\hline Niepołomice & 4008 & 130.54 & 3.26 & 140 & 28.63 & 0.9115 \\
\hline Kraków III & 8889 & 242.48 & 2.73 & 200 & 44.45 & 2.0555 \\
\hline
\end{tabular}

Table 8. Summary of the heating power of borehole exchangers for which a thermal reaction test was performed.

\begin{tabular}{|c|c|c|c|c|c|c|}
\hline BHE Location & $\begin{array}{l}\text { Heating Power for an } \\
\text { Interval of } 1 \text { min, } \mathrm{W}\end{array}$ & $\begin{array}{l}\text { Heating Power for an } \\
\text { Interval of } 10 \mathrm{~min}, \mathrm{~W}\end{array}$ & $\begin{array}{l}\text { Heating Power for an } \\
\text { Interval of } 60 \mathrm{~min}, \mathrm{~W}\end{array}$ & $\begin{array}{l}\text { Average Heating } \\
\text { Power, W }\end{array}$ & $\begin{array}{l}\text { Standard Deviation } \\
\text { of Heating Power, W }\end{array}$ & $\begin{array}{l}\text { Coefficient of } \\
\text { Variation, \% }\end{array}$ \\
\hline Łódź & 6645 & 6648 & 6636 & 6643 & 5.10 & 0.077 \\
\hline Szczecin & 10,008 & 10,008 & 10,009 & 1008.33 & 0.47 & 0.005 \\
\hline Polkowice & 7800 & 7799 & 7800 & 7799.67 & 0.47 & 0.006 \\
\hline \multirow[b]{2}{*}{ Rawa Mazowiecka } & 2509 & 2509 & 2508 & 2508.67 & 0.47 & 0.019 \\
\hline & 7009 & 7008 & 7009 & 7008.67 & 0.47 & 0.007 \\
\hline Kraków I & 7823 & 7824 & 7794 & 7813.67 & 13.91 & 0.178 \\
\hline Wolsztyn & 9523 & 9523 & 9523 & 9523 & 0.00 & 0.000 \\
\hline Gola Dzierżoniowska & 7014 & 7014 & 7014 & 7014 & 0.00 & 0.000 \\
\hline \multirow[b]{2}{*}{ Żarów } & 6000 & 6000 & 6000 & 6000 & 0.00 & 0.000 \\
\hline & 5997 & 5998 & 5996 & 5997 & 0.82 & 0.014 \\
\hline Białystok & 4390 & 4387 & 4390 & 4389 & 1.41 & 0.032 \\
\hline Wrocław & 4072 & 4071 & 4077 & 4073.33 & 2.62 & 0.064 \\
\hline Kraków II & 4813 & 4813 & 4810 & 4812 & 1.41 & 0.029 \\
\hline Niepołomice & 3998 & 4007 & 4008 & 4007.33 & 0.47 & 0.012 \\
\hline Kraków III & 8892 & 8890 & 8889 & 8890.33 & 1.25 & 0.014 \\
\hline
\end{tabular}


Table 9. Summary of the effective thermal conductivity $\lambda_{\text {eff }}$ of the borehole heat exchangers for which the thermal reaction test was performed (green-the lowest, red-the highest value of $\lambda_{\text {eff }}$.

\begin{tabular}{|c|c|c|c|c|c|c|c|}
\hline BHE Location & BHE Design & $\begin{array}{c}\lambda_{e f f} \text { for an Interval } \\
\text { of } 1 \mathrm{~min}, \mathrm{Wm}^{-1} \mathrm{~K}^{-1}\end{array}$ & $\begin{array}{c}\lambda_{\text {eff }} \text { for an Interval of } \\
10 \mathrm{~min}, \mathrm{Wm}^{-1} \mathrm{~K}^{-1}\end{array}$ & $\begin{array}{c}\lambda_{\text {eff }} \text { for an Interval of } \\
60 \mathrm{~min}, \mathrm{Wm}^{-1} \mathrm{~K}^{-1}\end{array}$ & $\begin{array}{c}\text { Average } \lambda_{e f f}, \\
\mathrm{Wm}^{-1} \mathrm{~K}^{-1}\end{array}$ & $\begin{array}{l}\text { Standard Deviation } \\
\text { of } \lambda_{\text {eff }}, \mathrm{Wm}^{-1} \mathrm{~K}^{-1}\end{array}$ & $\begin{array}{c}\text { Coefficient of } \\
\text { Varition, \% }\end{array}$ \\
\hline Łódź & 2-U-tube & 2.37 & 2.39 & 2.39 & 2.38 & 0.010 & 0.42 \\
\hline Szczecin & 1-U-tube & 2.63 & 2.83 & 2.28 & 2.58 & 0.230 & 8.91 \\
\hline Polkowice & 1-U-tube & 2.19 & 2.18 & 2.20 & 2.19 & 0.010 & 0.46 \\
\hline \multirow{2}{*}{ Rawa Mazowiecka } & 1-U-tube & 2.33 & 2.12 & 1.97 & 2.14 & 0.150 & 7.01 \\
\hline & 1-U-tube & 2.90 & 2.86 & 2.77 & 2.84 & 0.050 & 1.76 \\
\hline Kraków I & 1-U-tube & 2.11 & 2.00 & 1.83 & 1.98 & 0.120 & 6.06 \\
\hline Wolsztyn & 1-U-tube & 1.74 & 1.78 & 1.75 & 1.76 & 0.020 & 1.14 \\
\hline $\begin{array}{c}\text { Gola } \\
\text { Dzierżoniowska }\end{array}$ & 1-U-tube & 2.97 & 2.86 & 2.50 & 2.78 & 0.200 & 7.19 \\
\hline \multirow{2}{*}{ Żarów } & 1-U-tube & 2.50 & 2.70 & 2.50 & 2.57 & 0.090 & 3.50 \\
\hline & 1-U-tube & 2.80 & 2.74 & 2.70 & 2.75 & 0.040 & 1.45 \\
\hline Białystok & 1-U-tube & 2.53 & 2.50 & 2.39 & 2.47 & 0.060 & 2.43 \\
\hline Wrocław & 1-U-tube & 1.72 & 1.64 & 1.64 & 1.67 & 0.040 & 2.40 \\
\hline Kraków II & 2-U-tube & 2.07 & 2.03 & 1.93 & 2.01 & 0.060 & 2.99 \\
\hline Niepołomice & 1-U-tube & 2.66 & 2.64 & 2.50 & 2.60 & 0.070 & 2.69 \\
\hline Kraków III & 2-U-tube & 1.92 & 1.77 & 1.72 & 1.80 & 0.080 & 4.44 \\
\hline
\end{tabular}


In Table 9, the lowest values are marked in green and the highest values in red. It can be seen that most often the lowest values occur for analysis with averaging every $60 \mathrm{~min}$, and the highest for averaging every $1 \mathrm{~min}$. For design safety reasons (designing the number of BHEs), averaging every $60 \mathrm{~min}$ should be used for analysis.

Due to the analysis of the commercial thermal response tests data, the effective thermal conductivity $\lambda_{\text {eff }}$ for borehole heat exchangers located throughout Poland was determined. Calculations were made for three time intervals of measurement results averaging: $1 \mathrm{~min}, 10 \mathrm{~min}, 60 \mathrm{~min}$, in each individual case.

An important element for the analysis of the measurements was the rejection of the results recorded before and after conducting the test, as well as any anomalies, which could have been affected by external factors such as voltage drops, start-up and stabilization periods of the circulation pump operation, or the influence of atmospheric air temperature.

The output data of the conducted and analyzed tests were spreadsheets with a summary of all the parameters of the heat carrier flowing in the circulating system, recorded by the TRT device. For further analysis, additional calculations in the form of an average heat carrier temperature and the time from the beginning of the test and its natural logarithm were necessary.

By obtaining such data, it was possible to create appropriate graphs showing the relationship between the average temperature of the heat carrier, time, and the logarithm of time. A graph depicting the relationship between heating power, flow rate, and time was presented in order to determine their possible impact on the measurement process.

Slope factors were determined based on regression equations. The average heating power was calculated by summing the values recorded for each measurement and dividing it by the number of measurements. The depth of the exchanger, originating from the technical documentation, was given as additional information for each test.

The presented values of the effective thermal conductivity coefficient $\lambda_{\text {eff }}$ for each exchanger are similar and show no significant differences between each other. Only in four cases a discrepancy in results of more than $5 \%$ can be noticed, which may have been caused by external factors.

The calculated standard deviation and coefficient of variation values confirmed that the set heating power showed constancy and that any deviations from the average were small (less than $10 \%$ ). The same is true for the effective thermal conductivity factor (the variability of this parameter is only a few percent), which indicates small differences in conductivity depending on the sampling rate of the test. The heating power shows a small dispersion of values over the measurement process.

It has been confirmed that the directional coefficient of the regression line affects the value of effective thermal conductivity, but these are not very large discrepancies. This is due to the number of results making up the graph of the average temperature dependency on the logarithm of time. More data allow for more accurate determination of the parameters, however it makes it is easier to disrupt the correctness of the measurement process, affecting the final result.

\section{Conclusions}

The thermal response tests were performed for $100 \mathrm{~h}$ in BHEs of different design and identical lithology. TRT data averaging intervals of every $1 \mathrm{~min}, 10 \mathrm{~min}$, and $60 \mathrm{~min}$ were analyzed. Heat carrier temperature changes in time were recorded. The program used for the conversion of data from TRT apparatus were calculating the averages by an arithmetic mean method. It can be concluded that the most reliable (accurate) result would be reflected by a measurement with a time interval of every $1 \mathrm{~min}$. Such data will be the largest in quantity. Rock mass properties were identical. The effective thermal conductivity $\lambda_{\text {eff }}$ is dependent on various BHEs designs, heat carrier flow geometry, as well as sealing slurry parameters. The position of the pipes in relation to each other also seems important to consider. As shown on the graphs, the best effective thermal conductivity $\lambda_{\text {eff }}$ has occurred in BHE- 1 with a coaxial design. At the same time, this value is closest to the theoretical value of thermal conductivity of the drilled rocks $\lambda$. 
By analyzing the results of the thermal response tests, the value of effective thermal conductivity can be easily determined. For this purpose, it is necessary to create a graph of the relation between the average temperature of the heat carrier and the logarithm of the working time of the TRT apparatus. Then, a regression line of this function and its directional factor should be determined.

The directional factor of the regression line shows different values, depending on the time interval for the considered BHE. As a result, the final value of the effective thermal conductivity coefficient $\lambda_{\text {eff }}$ for this BHE is slightly different. It is influenced by the method of averaging the obtained results during the thermal response test. In the majority of described cases, these differences are not very significant, and the values are comparable. In two cases, they are slightly larger, possibly because it is easier to miss the moment of the ground thermal saturation and the temperature graph smoothing at intervals of $60 \mathrm{~min}$. It therefore appears that the interval of $1 \mathrm{~min}$ is more accurate for correct determination of the thermal parameters of the rock mass.

The results of the conducted analysis of the thermal response tests for the borehole heat exchangers located in Poland allowed to determine the directional coefficient of a regression line, and its influence on the effective thermal conductivity for individual exchangers, which was presented in Table 9.

Standard deviation and coefficient of variation values have confirmed that there were no significant deviations from the set value of heating power. They also showed that the effective thermal conductivity calculated for different time intervals shows little value variability.

Thermal conductivity values for each time interval, for the same exchanger, were similar in value. Investigated media have shown good potential for extensive installations acquiring heat from low temperature sources.

As shown in Table 9, the lowest values most commonly appear for analysis averaging every $60 \mathrm{~min}$, and the highest—for analysis averaging every $1 \mathrm{~min}$. For design safety reasons (designing the number of BHEs), safer values can be taken for analysis, i.e., averaging every $60 \mathrm{~min}$. A better way is to use the most accurate estimate ( 1 min averaging) and then simply include a safety margin for design safety reasons. Adding safety should be a quantifiable adjustment, which can be based on the lowest (safer) value of averaging, sensors uncertainty, and the impact of ambient temperature.

Author Contributions: Conceptualization, A.S.-S. and T.S.; methodology, T.S. and K.S.; software, K.S.; validation, A.G.; formal analysis, A.S.-S.; investigation, K.S. and P.Ż.; resources, K.T.; data curation, K.T.; writing-original draft preparation, T.S. and K.S.; writing—review and editing, A.G.; visualization, K.S.; supervision, T.S.; project administration, A.S.-S.; funding acquisition, T.S. All authors have read and agreed to the published version of the manuscript.

Funding: This research was funded by Polish Ministry of Science and Higher Education, grant number 16.16.190.779.

Conflicts of Interest: The authors declare no conflicts of interest.

\section{References}

1. Yoon, A.-Y.; Kang, H.-K.; Moon, S.-I. Optimal Price Based Demand Response of HVAC Systems in Commercial Buildings Considering Peak Load Reduction. Energies 2020, 13, 862. [CrossRef]

2. Zhou, W.; Pei, P.; Hao, D.; Wang, C. A Numerical Study on the Performance of Ground Heat Exchanger Buried in Fractured Rock Bodies. Energies 2020, 13, 1647. [CrossRef]

3. Sliwa, T.; Gonet, A. Otworowe wymienniki ciepła jako źródło ciepła lub chłodu na przykładzie Laboratorium Geoenergetyki WWNiG AGH (Borehole heat exchangers as heat or cool source on the basis of Laboratory of Geothermics of Drilling, Oil and Gas Faculty in AGH University of Science and Technology). Wiert. Naft. Gaz 2011, 28, 419-430. Available online: http://journals.bg.agh.edu.pl/WIERTNICTWO/2011-1-2/W_2011_12_36.pdf (accessed on 10 April 2020). (In Polish). 
4. Sliwa, T.; Knez, D.; Gonet, A.; Sapińska-Śliwa, A.; Szłapa, B. Research and Teaching Capacities of the Geoenergetics Laboratory at Drilling, Oil and Gas Faculty AGH University of Science and Technology in Kraków (Poland). In Proceedings of the World Geothermal Congress 2015, Melbourne, Australia, 19-25 April 2015; Paper No. 09012. pp. 1-14. Available online: https://www.geothermal-energy.org/pdf/ IGAstandard/WGC/2015/09012.pdf (accessed on 10 April 2020).

5. Sliwa, T.; Gołaś, A.; Wołoszyn, J.; Gonet, A. Numerical model of borehole heat exchanger in ANSYS CFX software. Arch. Min. Sci. 2012, 57, 375-390.

6. Acuña, J.; Palm, B. Distributed thermal response tests on pipe-in-pipe borehole heat exchangers. Appl. Energy 2013, 109, 312-320. [CrossRef]

7. Gultekin, A.; Aydin, M.; Sisman, A. Thermal performance analysis of multiple borehole heat exchangers. Energy Convers. Manag. 2016, 122, 544-551. [CrossRef]

8. Li, M.; Lai, A.C. Review of analytical models for heat transfer by vertical ground heat exchangers (GHEs): A perspective of time and space scales. Appl. Energy 2015, 151, 178-191. [CrossRef]

9. Sliwa, T.; Sojczyńska, A.; Rosen, M.A.; Kowalski, T. Evaluation of temperature profiling quality in determining energy efficiencies of borehole heat exchangers. Geothermics 2019, 78, 129-137. [CrossRef]

10. Fujii, H.; Okubo, H.; Nishi, K.; Itoi, R.; Ohyama, K.; Shibata, K. An improved thermal response test for U-tube ground heat exchanger based on optical fiber thermometers. Geothermics 2009, 38, 199-406. [CrossRef]

11. Raymond, J.; Therrien, R.; Gosselin, L. Borehole temperature evolution during thermal response tests. Geothermics 2011, 40, 69-78. [CrossRef]

12. Wagner, V.; Blum, P.; Kubert, M.; Bayer, P. Analytical approach to groundwater-influenced thermal response tests of grouted borehole heat exchangers. Geothermics 2013, 46, 22-31. [CrossRef]

13. Liuzzo-Scorpo, A.; Nordell, B.; Gehlin, S. Influence of regional groundwater flow on ground temperature around heat extraction boreholes. Geothermics 2015, 56, 119-127. [CrossRef]

14. Rouleau, J.; Gosselin, L.; Raymond, J. New concept of combined hydro-thermal response tests (H/TRTS) for ground heat exchangers. Geothermics 2016, 62, 103-114. [CrossRef]

15. Bandos, T.V.; Montero, A.; Fernandez de Cordoba, P.; Urchueguía, J.F. Improving parameter estimates obtained from thermal response tests: Effect of ambient air temperature variations. Geothermics 2011, 40, 136-143. [CrossRef]

16. Spitler, J.D.; Gehlin, S.E.A. Thermal response testing for ground source heat pump systems-An historical review. Renew. Sustain. Energy Rev. 2015, 50, 1125-1137. [CrossRef]

17. Gehlin, S. Thermal Response Test: Method Development and Evaluation. Ph.D. Thesis, Luleå University of Technology, Luleå, Sweden, 2002. Available online: http://tu.diva-portal.org/smash/get/diva2:991442/ FULLTEXT01.pdf (accessed on 30 April 2020).

18. Mogensen, P. Fluid to Duct Wall Heat Transfer in Duct System Heat Storage. In Proceedings of the Int. Conf. On Subsurface Heat Storage in Theory and Practice, Stockholm, Sweden, 1983; pp. 652-657.

19. Nejad, P.E.; Badache, M.; Corcoran, A.; Bernier, M. Calibration of thermal response test (TRT) units with a virtual borehole. Geothermics 2019, 79, 105-113.

20. Sun Chang, K.; Jun Kim, M. Thermal performance evaluation of vertical U-loop ground heat exchanger using in-situ thermal response test. Renew. Energy 2019, 87, 585-591. [CrossRef]

21. Choi, W.; Kikumoto, H.; Choudhary, R.; Ooka, R. Bayesian inference for thermal response test parameter estimation and uncertainty assessment. Appl. Energy 2018, 209, 306-321. [CrossRef]

22. Beier, R.A.; Smith, M.D.; Spitler, J.D. Reference data sets for vertical borehole ground heat exchanger models and thermal response test analysis. Geothermics 2011, 40, 79-85. [CrossRef]

23. Zhang, C.; Guo, Z.; Liu, Y. A review on thermal response test of ground-coupled heat pump systems. Renew. Sustain. Energy Rev. 2014, 40, 851-867. [CrossRef]

24. Raymond, J.; Lamarche, L.; Malo, M. Field demonstration of a first thermal response test with low power source. Appl. Energy 2015, 147, 30-39. [CrossRef]

25. Franco, A.; Moffat, R.; Toledo, M.; Herrera, P. Numerical sensitivity analysis of thermal response tests (TRT) in energy piles. Renew. Energy 2016, 86, 985-992. [CrossRef]

26. Zarrella, A.; Emmi, G.; Graci, S.; De Carli, M.; Cultrera, M.; Santa, G.D.; Galgaro, A.; Bertermann, D.; Müller, J.; Pockelé, L.; et al. Thermal Response Testing Results of Different Types of Borehole Heat Exchangers: An Analysis and Comparison of Interpretation Methods. Energies 2017, 10, 801. [CrossRef] 
27. Gustafsson, A.-M.; Westerlund, L. Multi-injection rate thermal response test in groundwater filled borehole heat exchanger. Renew. Energy 2010, 35, 1061-1070. [CrossRef]

28. Zhang, C.; Chen, P.; Liu, Y. An improved evaluation method for thermal performance of borehole heat exchanger. Renew. Energy 2015, 77, 142-151. [CrossRef]

29. Loveridge, F.; Powire, W.; Nicholson, D. Comparison of two different models for pile thermal response test interpretation. Geothermics 2014, 9, 367-384. [CrossRef]

30. Yu, X.; Zhang, Y.; Deng, N.; Ma, H.; Dong, S. Thermal response test for ground source heat pump based on constant temperature and heat-flux methods. Appl. Therm. Eng. 2016, 93, 678-682. [CrossRef]

31. Sliwa, T.; Gonet, A. Theoretical model of borehole heat exchanger. J. Energy Resour. Technol. 2005, 127, 142-148. [CrossRef]

32. Signorelli, S.; Basetti, S.; Pahud, D.; Kohl, T. Numerical evaluation of thermal response tests. Geothermics 2007, 36, 141-166. Available online: 10.1016/j.geothermics.2006.10.006 (accessed on 10 April 2020). [CrossRef]

33. Sliwa, T.; Kotyza, J. Application of existing wells as ground heat source for heat pumps in Poland. Appl. Energy 2003, 74, 3-8. [CrossRef]

34. Sliwa, T.; Rosen, M.A.; Jezuit, Z. Use of Oil Boreholes in the Carpathians in Geoenergetic Systems: Historical and Conceptual Review. Res. J. Environ. Sci. 2014, 8, 231-242. [CrossRef]

35. Sliwa, T.; Kruszewski, M.; Zare, A.; Assadi, M.; Sapińska-Śliwa, A. Potential application of vacuum insulated tubing for deep borehole heat exchangers. Geothermics 2018, 75, 58-67. [CrossRef]

36. Sapińska-Śliwa, A.; Rosen, M.A.; Gonet, A.; Kowalczyk, J.; Sliwa, T. A new method based on thermal response tests for determining effective thermal conductivity and borehole resistivity for borehole heat exchangers. Energies 2019, 12, 1072. Available online: https://www.mdpi.com/1996-1073/12/6/1072/pdf (accessed on 10 April 2020).

37. Sliwa, T.; Rosen, M.A. Natural and artificial methods for regeneration of heat resources for borehole heat exchangers to enhance the sustainability of underground thermal storages: A review. Sustainability 2015, 7, 13104-13125. [CrossRef]

38. Perina, T. Derivation of the Theis (1935) Equation by Substitution. Ground Water 2010, 48, 6-7. [CrossRef] [PubMed]

39. Eklöf, C.; Gehlin, S. TED—A Mobile Equipment for Thermal Response Test. Master's Thesis, Lund University, Lund, Sweden, 1996.

40. Gonet, A.; Sliwa, T.; Stryczek, S.; Sapińska-Śliwa, A.; Jaszczur, M.; Pająk, L.; Złotkowski, A. Metodyka Identyfikacji Potencjału Cieplnego Górotworu Wraz z Technologia Wykonywania i Eksploatacji Otworowych Wymienników Ciepła (Methodology for the Identification of Potential Heat of the Rock Mass Along with Technology Implementation and Operation of the Borehole Heat Exchangers), 1st ed.; Gonet, A., Ed.; Wydawnictwa AGH: Krakow, Poland, 2011; p. 439. (In Polish)

41. Somerton, W.H. Thermal Properties and Temperature-Related Behavior of Rock/Fluid Systems, 1st ed.; Elsevier: Amsterdam, The Netherlands, 1992; p. 256.

42. Plewa, S. Rozkład Parametrów Geotermalnych na Obszarze Polski, 1st ed.; Wydawnictwo CPPGSMiE PAN: Krakow, Poland, 1994; p. 138. (In Polish)

43. Sapińska-Śliwa, A. Efektywność Pozyskiwania Ciepła z Górotworu w Aspekcie Sposobu Udostępniania Otworami Wiertniczymi (Effectiveness of Heat Recovery from Rock Mass in the Context of the Production Method by Means of Boreholes), 1st ed.; Wydawnictwa AGH: Krakow, Poland, 2019; p. 319. (In Polish)

(C) 2020 by the authors. Licensee MDPI, Basel, Switzerland. This article is an open access article distributed under the terms and conditions of the Creative Commons Attribution (CC BY) license (http://creativecommons.org/licenses/by/4.0/). 